\title{
The complementarity of divergent historical imaginations: narratives of mobility and alterity in contemporary Liberia
}

\author{
Maarten Bedert \\ Max Planck Institute for Social Anthropology, Halle (Saale), Germany
}

\begin{abstract}
Since the end of the civil war in Liberia (1989-2003), inter-ethnic tensions are often identified as potential causes for future conflict both by local actors and by analysts. In this article, I address how the past serves as a resource in the constitution of inter-ethnic relations and describe the divergent ways in which the past is imagined among the Dan and the Mandingo, two ethnic groups in the border region of Liberia. The Dan consider themselves autochthonous in the region and think of the Mandingo as 'strangers from Guinea'. Even though Dan derive political authority from these autochthony claims, relations between landlords and strangers rely on mutual recognition and reciprocity. Rather than competing autochthony claims, collective Mandingo representations are inspired by a divergent historical imagination. Whereas the Dan narratives evolve around kin relationships and a particular locality, Mandingo historical imagination is set in a much wider national and regional framework. They stress their belonging to the transnational Mandingo diaspora across West Africa and claim the right to citizenship based on their role in the development of the Liberian nation. I argue that the divergent historical imagination that is reproduced at the collective level among the Mandingo allows their inscription into the autochthonous Dan discourses through which they can more easily accept their position as strangers in more personal narratives. In the end, this unlikely compatibility illustrates the integrative potential of apparently different categories.
\end{abstract}

\section{ARTICLE HISTORY}

Received 7 October 2016

Accepted 8 January 2017

\section{KEYWORDS}

Liberia; ethnic identity; historical imagination; conflict and integration

\section{Introduction}

The aftermath of the civil war that engulfed Liberia and its neighbours between 1989 and 2003 has seen the emergence of a politicised ethnic self-consciousness. Memories of past experiences of inter-ethnic relations are being re-interpreted in light of new tensions. For instance, land conflicts are interpreted along ethnic lines as former refugees return to find their homes occupied. Claims to land are closely linked to notions of citizenship and belonging (Ammann \& Kaufmann, 2014; Munive, 2010). As such, the rights of returning refugees are questioned. These not only relate to recent episodes of forced mobility but also in light of past migrations. 


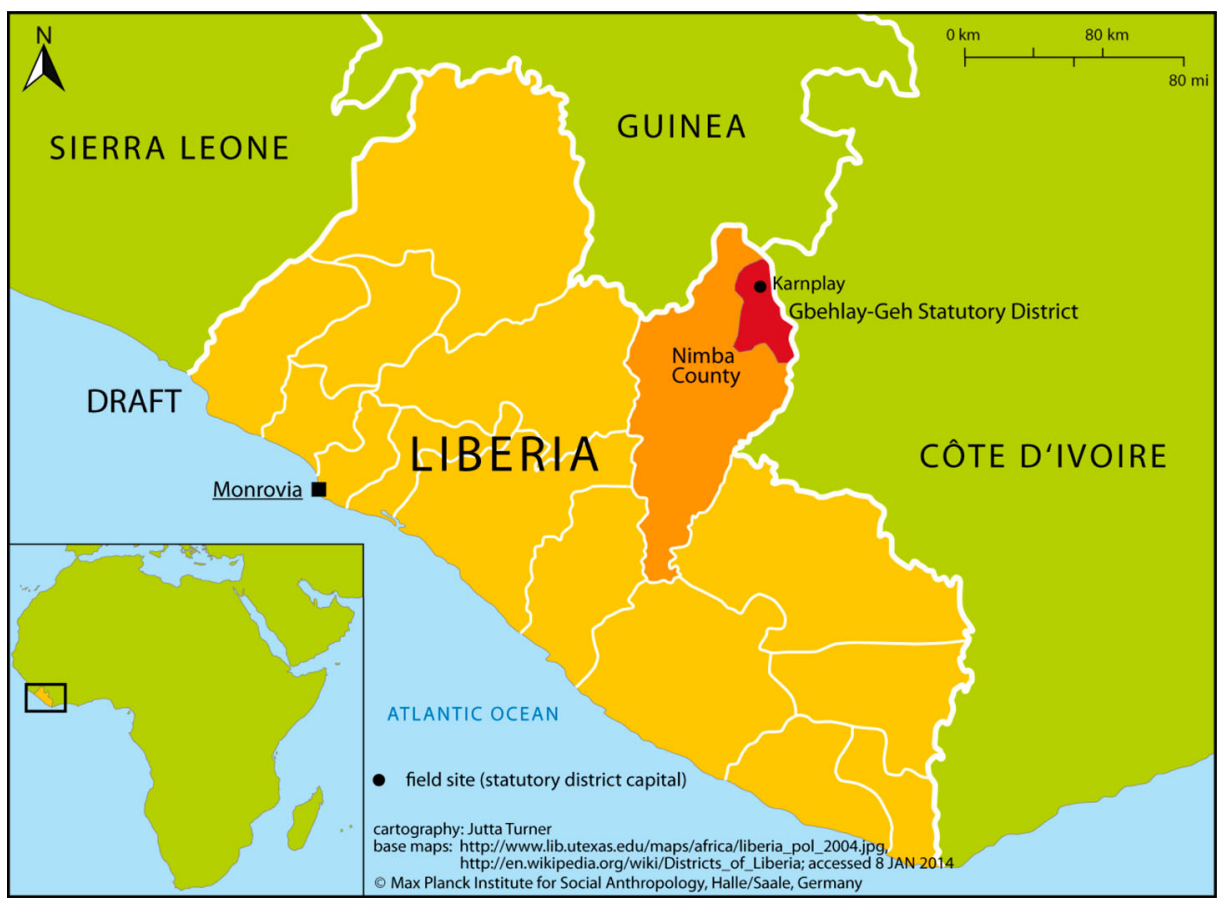

Figure 1. Gbelay-Geh Statutory District, the fieldwork location, within Liberia.

In this article, I analyse the articulation of ethnic identities and more specifically the importance of mobility in the divergent ways in which these are imagined among the Dan, on the one hand, and the Mandingo, on the other hand. Dan is the ethnonym used by those who consider themselves autochthonous in the north-eastern border region of Nimba County and who derive political and ritual authority from being the first settlers in this territory (Figure 1). The Mandingo people live in the LiberianGuinean-Sierra Leonean border region and beyond (including Guinea, Mali, Senegal, Gambia and Guinea-Bissau). The latter are generally considered to be strangers and latecomers by the Dan and are, consequently, politically subordinated as they have no right to political leadership positions or hold only limited ritual authority (cf. Bräuchler \& Ménard, 2017).

Rather than competing autochthony claims, Dan and Mandingo each have a different way to imagine the past in which pivotal moments do not compete. ${ }^{1}$ This paper explores the imaginaries of movement (cf. Glick Schiller \& Salazar, 2013) and mobility among the Mandingo. More especially, it elaborates on how long-term regional migration patterns inform the constitution of an ethnic identity that diverges from the autochthony discourses among the Dan. It is this imaginary of a regional identity that constitutes a sense of belonging and a collective ethnic identity among the Mandingo and justifies their contemporary claims to citizenship (see Bräuchler \& Ménard, 2017; Chamberlain \& Leydesdorff, 2004). I argue that the relationship between the Dan and Mandingo is a complex one that constantly shifts between inclusion and distinction. There is a distinct difference between formal narratives that constitute (ethnic) identities and the situated invocation of these narratives. I will demonstrate the ways in which Mandingo are able 
to shift between a collective Mandingo and a Dan historical imagination, depending on the interactional context they find themselves in.

Data for this article were collected during 17 months of fieldwork in Gbelay-Geh Statutory District in Nimba County, Liberia, between July 2011 and July 2013. While based in Karnplay city, the district's administrative headquarters, I conducted interviews with both Dan and Mandingo elders. These historical narratives were substantiated during informal discussions and by participating in public events and rituals in which the relations between Mandingo and Dan were articulated.

In this article, I first sketch the significance of 'The Mandingo question' in the post-war era and point out how the relationship between Dan and Mandingo implies ongoing potential for conflict. Second, I outline the key components that give shape to a collective Mandingo historical imagination and indicate how these diverge from a Dan historical imagination. Third, I demonstrate the way in which Mandingo shift away from this type of historical imagination and inscribe themselves into a Dan way of imagining the past and adopt the position of politically and socially subordinated strangers. In so doing, I indicate how this dynamic creates a potential for integration rather than conflict. Finally, I provide further insight into how this integrative potential between Dan and Mandingo differs from other parts of the region.

\section{The issue at stake: framing 'the Mandingo question' in the post-war era}

The civil war in Liberia (1989-2003) has triggered the rise of a politicised ethnic self-consciousness. Events that occurred during the war are invoked as a scapegoat to re-interpret relations between the Dan and Mandingo in new lights. In particular, memories of past migrations are invoked in order to legitimise contemporary citizenship claims. In this, Mandingo are considered strangers from Guinea rather than Liberian citizens. The fact that many Mandingo sought refuge in Guinea during the war (Fairhead, 2010, pp. 78-80) makes their return and their claims to land and political authority heavily contested. In other words, migration and mobility in relation to the experience of violence informs discussions on belonging and membership.

In popular media, policy reports and academic publications alike, the Mandingo are looked at with suspicion since the end of the war in Liberia (Højbjerg, 2016; Richards et al., 2005). The war officially started with the invasion led by Charles Taylor and his National Patriotic Front of Liberia. As he passed through Nimba County, he quickly gained support from a lot of Mano and Dan people as they felt persecuted by the regime of President Samuel K. Doe. In the north of the country, Mandingo are perceived to be close collaborators of former President Samuel Doe and are looked upon as traitors by many Loma, Mano and Dan people. Under his regime, they are said to have enjoyed considerable economic benefits and privileges and to have supported his raids in Nimba County in the 1980s (Ellis, 1999, pp. 57-62). With the overthrow of president Doe, Taylor took over power in 1997. His autocratic regime led to the emergence of new factions like, among others, the Mandingo-led Liberians United for Reconciliation and Democratisation, which gained ground among many refugees based in camps or among communities in Guinea (Fairhead, 2010, p. 78). The second phase of the war (1999-2003) ended with the signing of a comprehensive peace agreement in Accra and 
with Taylor going into exile before being arrested and appearing before the Special Court for crimes committed in the Sierra Leonean civil war.

Whereas Dan and Mandingo seemed to be pinned against one another during the war, the 'Mandingo question' is more prominent in post-war Liberia as it refers to the fact that, even though they are a minority group in much of the country, the Mandingo make claims to land, to local and national political leadership and to citizenship as they returned from refugee camps (Bøas, 2009; Bøas \& Dunn, 2013; Højbjerg, 2010, pp. 276-277; McGovern, 2012; Munive, 2010). In many cases, these claims are not met with sympathy from the local communities in the transitional Upper Guinea forest zone, ${ }^{2}$ among them the Dan, who claim autochthony in the region. Dan historical imagination is constituted and articulated around landlord-stranger reciprocal relations in which landlords are considered the first settlers in a territory and strangers settled at a later stage. In her contribution, Ménard (2017) elaborates on the social and political implications of this type of relationship. She stresses, in particular, the importance of reciprocity that characterises exchange between both groups. Landlord-stranger relationships are often articulated through historical narratives that are constructed around pivotal moments. Knowledge about the establishment of a first settlement (Dan: kpanaa) in a virgin territory is remembered and transmitted as are memories of alliances with strangers that were established through marriage. In this logic, strangers are considered to be politically and ritually subordinate to the landlords (d'Azevedo, 1962a; Fortes, 1975; Højbjerg, 1999; Lentz, 2013; Murphy \& Bledsoe, 1987; Trajano Filho, 2010). ${ }^{3}$ Collectively, Mandingo are considered strangers to the Dan.

Mandingo are reproached for breaking traditional bonds and norms associated with their position as strangers in their quest for economic dominance. In an attempt to forge a strong connection between landlords and their strangers, Dan families often 'give their daughters' to strangers for marriage. Mandingo are accused of not reciprocating these gestures and of 'keeping their daughters to themselves' (see Ménard, 2017). By not 'giving' away their daughters, they evade the establishment of ritual, political and economic alliances between families following the logic behind landlord-stranger reciprocity relations. For these reasons, Mandingo were among the first to flee the region when the fighting broke out. As they felt they were under attack, many of them fled to Guinea. Today, some are still residing in Guinea, afraid to return and face repercussions. Many who did return faced a difficult struggle for their property and their economic status (Bøas \& Dunn, 2013; Munive, 2010, p.16). The antagonistic relation between both groups and the notion that their rightful home is in Guinea is often interpreted as a potential cause for further violent conflict within Liberia and the region.

As I will show, however, the recent collective experience of the war and the existence of a divergent historical imagination in the context of Dan/Mandingo relations have an integrative dimension that relieves potential for conflict. In order to demonstrate these claims, I rely on a detailed empirical analysis of narratives through which ethnic identities are constituted and articulated. A differentiation is made between formal encounters like the collecting of oral histories and informal, even improvised, moments in which ethnic identity turned out to be of significance (see Borch, 2017). Both of these sources contribute to an understanding of how a Mandingo ethnic identity is constituted and how it serves as a way through which actors organise social encounters and experiences. Based on this phenomenological approach, I consider the articulation of an ethnic 
identity in moments of interaction as a performative act of identity. It is a way of aligning oneself with a particular group that is recognisable by others (Le Page \& Tabouret-Keller, 1985). This is done, as the subsequent examples will show, through speech acts and actions such as the performance of formal narratives and oral histories as well as through ritual actions.

\section{Understanding Mandingo historical imagination}

Forced migration as a result of war is not the only way in which mobility influences discussions of belonging. Whereas the recent experience as (returning) refugees seems to stress dynamics of exclusion and conflict, earlier waves of migration inform the Mandingo historical consciousness. These earlier waves of migration serve as a way to stress belonging and citizenship in a more inclusive way as they are crucial in establishing membership in local communities as well as citizenship at the national level. Rather than merely tracing their origins back to Guinea, Mandingo historical imagination consists of a complex mix of wider, regional West African elements and Liberian nationalism. The latter is supported by the fact that government pacification in the early twentieth century allowed the Mandingo migration from contemporary Guinea and gradual settlement among the Dan to occur. It facilitated the stabilisation of Mandingo presence in a complex triangular exchange. Ford (1990, pp. 1-2) points out how a history of leadership structures and the political economy among the Dan cannot be written without paying attention to the role played by Mandingo traders, on the one hand, and the impact of the pacification, on the other hand. Rather than encounters between two or more separated groups, Ford (1990) stresses how Mandingo and Dan historical trajectories in Nimba County are intertwined. Mandingo who settled among the Dan in the early twentieth century were given wives and land, and these gifts were reciprocated by the strangers as they provided cash money, education opportunities and opening markets and trade networks to the Dan. Their actions continue to inspire their claims to land and citizenship today. The following two quotes illustrate both the regional and the national aspect of the way the past is imagined.

In a discussion with the elders of the Mandingo community in Karnplay City, where fieldwork was conducted, their spokesperson opened the discussion by stating:

You see, the question of origin, when it comes to West Africa has some controversies. Understanding ourselves, where we come from, historically ... West Africa was made of kingdoms, empires. It is the range and limits of the kingdoms of Mali, Songhay and Ghana are those we can talk about today. The kingdoms or the empires that existed before Liberia, Guinea, Sierra Leone and Ivory Coast have some lasting impact about which we can say something relevant. For example, with the journey of Benjamin JK Anderson ${ }^{4}$ into the hinterland in the sixteenth century, he co-opted half of the forest region of Guinea to Liberia, that is, all the way to Musadu. And Musadu is beyond Beyla. All this occurred before the fall of the great slave trade. As a result, migration started, either because of war or the fear of war or because of hunger or for business or simply because the need to live. Some of these people that we have named, they settled in Beyla, settled in Bopulu, settled inside Lofa County. They started descending down this way. As far as my knowledge is concerned, for my very family, they resided in parts that now belong to Sierra Leone. Others resided where the Guinean government came. Today this is Guinea because the Liberian government was lazy. They failed to make their presence, their authority felt in those areas. 
In the first sentence of this quote, a reference is made to West Africa and a number of historical kingdoms. In this way, the speaker presents himself as part of a much larger, regional religious and trade network. In Dan oral histories or personal genealogies, this type of expression or link to a larger West African network would make little sense since the stress is on highly localised settlements. For the Mandingo, the reference to West Africa and the subsequent narrative of migration that ensued becomes a meaningful category of identification in this regard (cf. Tonkin, 1990). In a later statement during the same interview, responding to my Dan research assistant, the spokesperson stated:

we are great people, not small people like you. No, we are the powerful minority, very powerful. My great grand uncle, King Sao Bossu gave credence to the establishment of this country. Only people who don't have wealth, they will look at Mandingo man and say he is stranger. I say, you are more of a stranger than me.

With this second quote, the historical significance of the Mandingo for the nation is underscored. By referencing Sao Bossu, the leader of the historical Condo federation that existed in Western Liberia between the second half of the eighteenth and the first half of the nineteenth century who helped welcoming the Americo-Liberian settlers (Holsoe, 1966), and mentioning the pivotal role he played in the establishment of the country, the speaker aligns himself with a historically significant elite and justifies his right to citizenship in contemporary Liberia. Both quotes taken together give a clear indication of the shape that the Mandingo historical imagination takes. In contrast with other contributions as part of this issue, this early migration here is not forced upon actors due to warfare but to longer term patterns of migration and mobility that are invoked to justify and legitimise contemporary social relations. Mandingo consider their mobility as a privilege and as related to a West African elite. With the sentence, 'you are more of a stranger than me', Mandingo dismiss a smaller scale, more localised history and value the memory of a 'greater' history that is wider in scope, both geographically and in time.

It is important to note that the invocation of the past and the formation of a certain historical imagination are not arbitrary but result from actual long-term historical processes. Contrary to dominant historiography, Højbjerg (2010, pp. 280-281) has identified a similar divergent historical imagination among Mandingo in neighbouring Lofa county. Højbjerg (2016) has described the Mandingo as a transnational ethnic group. ${ }^{5}$ The term refers to people spread out all over the Upper Guinea Coast. More than their geographical distribution, he notes how the term is often used to refer to important West African trade diasporas for whom Islam also played an important role. In this particular case, Mandingo is used to refer to those people who consider the Konya region in present-day Guinea and the city of Musadu as their mythical homeland (cf. Geysbeek, 2002, p. 293).

The Mandingo migration towards the Atlantic coast has emerged as a gradual process. Analysts have linked it to the rise and decline of the Mali Empire in the fifteenth century (cf. Geysbeek, 2002; Person, 1971). Mandingo have migrated from Guinea in order to gain control over trade routes between the coast and the interior (Ford, 1990, pp. 49-52; Konneh, 1992, pp. 73-74). Besides traders, clerics have also been instrumental in that they brought Islam to the so-called forest people. This gradual migration started most likely from the administrative region of Beyla (circle de Beyla) as part of the Konyan. In the late eighteenth and the early nineteenth century, Mandingo started moving towards the coast because of a complex combination between push and pull factors: 
pushed to the south by the French colonial troops who arrived in Guinea and pulled to the coast by the opportunities presented after the arrival of the Americo-Liberians. They served as 'entrepreneurs between culturally different people' (Ford, 1990, p. 59). Whereas the Northern Mandingo dreaded venturing into the thick forests, the Konyan, a group of Mandingo who trace their ancestry to the Konya region in Guinea and who are differentiated from the Manya (Højbjerg, 2016, p. 264), were prepared to establish contacts in the forest and were hoping to gain direct access to the European traders at the coast, entering through what is today Lofa County in the northwest of the country.

By 1840, Americo-Liberian settlers, freed slaves who returned from the US and established the Liberian state, got wind of the importance of these Mandingo traders (cf. d'Azevedo, 1994; Fairhead et al., 2003). After establishing Monrovia as their basis, the trade route from the newly established capital, passing Bopulu, Voinjama (the capital of Lofa County) and Macenta (Guinea) towards Musadu, became of particular interest (Fairhead, 2010, pp. 82-83). Initial Mandingo presence occurred along routes in the west of the country. These early movements consisted of violent and disruptive episodes as Mandingo traders tried to take control over regional trade routes (Ford, 1990, p. 63; Højbjerg, 2010, p. 284). ${ }^{6}$ At that time, the Nimba Mountain region fell outside of the area of influence and traders still feared travelling regularly or establishing trading posts in the area. Trade occurred but mainly through relay, with goods or slaves passing hands as they progressed (Ford, 1989, 1990, pp. 57-60). These trading connections are significant, both in the history of Liberia and in the constitution of a historical consciousness among the Mandingo.

The introduction of the hut tax by the Americo-Liberians, which became widespread in Nimba County after 1918, made that trade opportunities among Mandingo traders increased and eventually led to the growth of permanent settlements among the Dan (Ford, 1990, p. 57, 1995). The Liberian government was constantly on the verge of bankruptcy and used the money collected through taxes to repay international loans as well as finance their everyday operations (Gershoni, 1985, pp. 14-15). The implications for the Dan were the growing need for cash (nas puu) where barter was the main form of exchange before. Besides rich men (boume) or government functionaries, Mandingo provided direct access to cash money through their trading activities (Ford, 1990, p. 232).

Not long after the pacification, Mandingo elders recall how Karnplay was designated as an urban area. One of the first District Commissioners, a local representative of the Americo-Liberian government in Monrovia, urged Mandingo traders to settle in these newly designated towns. In order to help Karnplay to become a central node, he thought it would benefit from increased business and trade networks. ${ }^{7}$ As a result, many of the Mandingo who were dispersed throughout the district settled in Karnplay. Mandingo stressed on several occasions how they were the first to build both a mosque and an Arabic school in the town in the early 1920s. ${ }^{8}$ During a discussion on the collective Mandingo memory, it was pointed out how they 'liberated the Dan from ignorance and illiteracy, but not with a gun'. The main elder representing the Karn family, a descendant from the Dan founder of the town, was a student of the first Mandingo settlers. The discourse that is being maintained by the Mandingo articulates how they have played a crucial part in building the town of Karnplay as well as the country and the nation state by closely cooperating with the Americo-Liberian settlers, by bringing modern education and monotheistic religion, three symbols closely associated with a national elite. 
This nationalistic aspect of Mandingo historical imagination is often played out in the aftermath of the war. The Mandingo historical consciousness and self-conception has been added up with a discourse on suffering. Suffering as articulated in relation to national belonging creates a platform that might enhance national consciousness (Kohl \& Schroven, 2014). In this line of discourse, Mandingo stress their involvement in building the nation but lament the lack of respect and recognition they have received for their efforts. These sentiments are expressed through simple expressions like 'going into exile' when they left for Guinea during the war rather than having returned 'home'. A frequent claim in Liberia with regard to the Mandingo population is that, as 'strangers from Guinea', they simply returned to their homeland when the war broke out. In contrast, by using the expression of going into exile they stress their connection to Liberia and how they were forced to leave. As such, after the war, they returned back home to Liberia. This strategic expression has significant implications with regard to claims to citizenship in a fluid border zone marked by high mobility and cross-border movement. Mandingo rely on the articulation of national belonging in order to legitimise their local belonging.

\section{The integrative potential of divergence}

The emergence of the divergent repertoires through which belonging is articulated might appear to be dichotomous or mutually exclusive (for a comparative perspective, see Bräuchler, 2017) as they represent the difference between two groups. However, I differentiate between collective narratives through which an ethnic identity is constituted and personal narratives by Mandingo in which they are able to switch between a Mandingo historical imagination and a Dan historical imagination. They construct personal narratives around the pivotal moments that Dan also make explicit reference to: territory and kinship. Mandingo, in other words, inscribe themselves into local Dan communities as strangers and, in so doing, accept a politically subordinate position rather than being excluded from the community entirely.

In an interview with one of the Mandingo elders, I wanted to find out more about his father's role in the building of Karnplay as it was originally a small Dan settlement that turned into a more diverse town. As one of the main protagonists of the Mandingo committee of elders, he had relied very strongly on the divergent historical imagination and the implications it has for the constitution of a collective Mandingo identity by stressing his affiliation with Islam and historical kingdoms that spread out over much of West Africa. On this occasion, he explained how his 'original' plot of land, today referred to as his 'Kingdom', is located along the main road and exploited as a business area with a video club and a teashop. This piece of land was given to his father by the Dan chief when he arrived in Karnplay. His father was a visionary and a powerful diviner who migrated from one place to another to exploit his talents. However, when he passed through Karnplay, people jumped on him and arrested him.

Apparently somebody had dreamt about a stranger passing through the town and how he should not be allowed to pass on as he would be instrumental in the development of the town. When he got arrested, he was scared for his life as he was carried to the chief's compound. While he thought he would be killed or sold into slavery, the chief offered him cow meat, more than he could eat, and was asked to stay. To seal the deal, the chief offered him his daughter and a piece of land. 
To further indicate the importance of his family's legacy, he explained how many prominent Dan in the community had a middle name that carried the initial of his father's first name. He also stressed how, over generations, they 'married their [Dan] sister', so as an in-law he would not be allowed to harm any of the family members. However, his high standing allows him to maintain joking relations with many Dan residents in Karnplay (cf. Radcliff-Brown, 1940). These jokes, playing on the social position of landlords and strangers, demonstrate the ambiguous nature of his social position within the community. With references to this 'original plot of land' and to marriage practices, he inscribes himself firmly into a repertoire of Dan historical imagination. Moreover, a metaphysical connection is established by mentioning his father's responsibility of bringing prosperity to the town. This type of composition (Guyer \& Belinga, 1995, p. 103) serves as a prime illustration of the way in which strangers are recognised before they are incorporated into the community of the landlord. In other words, difference and alterity here have a potential for integration rather than for conflict. The individual story differs from the collective Mandingo narrative and follows more closely an autochthonous Dan logic. This way of crafting personal narratives is common.

In this example, belonging is articulated in a formal narrative where origin is openly elaborated upon. Contrary to this, I encountered more situational contexts where belonging was articulated. In the following example, one Mandingo man articulates landlord-stranger reciprocity relations based on marital exchange and kinship, again, one of the pillars of the Dan historical imagination. It shows how divergence in the way the past is remembered and how this divergence constitutes collective identities does not presume exclusion. Rather, the idea of a collective identity is appropriated in personal narratives to allow incorporation and (temporal and partial) integration. The wedding between an upcoming Dan trader descendant from the Karn quarter, i.e. belonging to the Karn family who are considered the autochthonous founders of Karnplay, and his long-term Dan girlfriend who originated from a different quarter in Karnplay had been long awaited and duly announced. On the day in question, a number of cars were lined up in front of her father's house, a rare sight in Karnplay. Curious passers-by tried to figure out what was going on. The family of the bride was inside with the future groom negotiating the dowry payment. This celebration was considered a proper Dan ceremony fulfilling all the required ritual prescriptions. A bit further away from the festivities, safely on a bench across the street, a group of younger men was engaged in heavy discussions. One of them was a Mandingo man, son of one of the community elders, and in informal discussions he often took strong positions when it comes to the discrimination against Mandingo, especially by government officials and security personnel.

On this occasion, he seemed rather upset. To paraphrase his point of view: the amount for the dowry that had been offered by the groom's family was a slap in the face according to him. 'A big business man like that, if he pays dowry today, it should also calculate all the good things his wife will bring for him in the future.' In his view, she has been the one who has contributed to his success so far and these efforts should be recognised. Because of his apparent concern with the ongoing negotiations I asked him what all this is to him since I could not see how this could affect him. He jumped up and stated how he is giving his mother away today and how he is on his way of becoming an in-law to the Karn family. With this reference to marriage and kin relations, this Mandingo man articulated belonging by invoking a key element of the Dan historical imagination. When I pointed out that 
he is the son of a prominent Mandingo trader in the community and that I had a hard time seeing how this wedding would make him an in-law to the Karn lineage, he explained that his mother came from the same place as the bride. For this particular event, he 'belonged' to her quarter and therefore to the family of the bride. Matrilateral ties in this case are the way to make an alliance. Of course, on this occasion and from where he found himself this sort of articulation of belonging is more playful than political.

\section{The experience of violence and remembering a shared past}

There are two possible explanations for the ways in which inter-ethnic opposition between Mandingo and Dan showcase integrative dimensions rather than only exclusionary ones. Mandingo abandon their focus on mobility and movement and inscribe themselves - as politically subordinate strangers - in a local logic of autochthony because of, first, the common experience of violence during the war. Second, there is the long history of cohabitation and exchange. Both of these are constituted in narratives that continue to be reproduced within the public sphere. The argument here is that, contrary to the representation of autochthony as a discourse of exclusion, Mandingo recognise the inclusion and reciprocity that is granted to recognised strangers. Moreover, their historical imagination stressing mobility and wider West African networks continues to serve as an escape when the limits to reciprocity linked to autochthony discourses are reached. It legitimises their contemporary claims to citizenship and valorises their presence in alternative ways. It is important to notice here that these experiences are relatively local and cannot necessarily be extrapolated to the rest of the count(r)y. ${ }^{9}$

When it comes to public discourse, both Dan and Mandingo are keen on stressing how Karnplay was the first place where reconciliation started after the war. This statement reflects the predominant national and internationally driven peace-building discourse that stresses national integration and reconciliation (compare Borch, 2017, for a case where such international rhetoric is rather counterproductive). Also, it is an indication of how integration through differentiation is achieved. Apparent integration and cooperation is a sign here of the management of differentiation. Much to my surprise, discussions about the war among the Mandingo proved to be much easier than anticipated. Although there were difficult passages concerning the damages done to the mosque ${ }^{10}$ and the destruction of houses and the killing of family members in cold blood, there was consensus that this violence was initiated by 'outsiders'. Upon his inauguration as president, Samuel K. Doe assigned military personnel to serve in the capacity of district commissioner. In the committee of Mandingo elders, one member who had not talked a lot before took the floor and explained how the commissioner and his troops killed 47 Mandingo in town and how they burned 139 Mandingo houses. ${ }^{11}$ He had to watch how his own mother and sister were executed. After frowning upon this former commissioner, he mentioned how a local Dan war hero protected many of the Mandingo settlements and citizens. While seeking refuge in the early stages of the war, several residents in Karnplay also mentioned how Dan and Mandingo offered one another a hiding place in the wake of danger. A bit later in the interview, one of the Mandingo elders asked me to look outside and asked me what I saw. I responded by saying I saw a truck being loaded with cash crops. He noticed that all of these are 'aliens'. This is the biggest threat to stability nowadays. 
The distinction between strangers and aliens in this way is indicative. 'Alien' is a common colloquial expression to refer to non-citizens. The differentiation from the category of strangers is significant in the sense that they operate in a national frame of reference here. It is the aliens, today, who cause problems rather than the 'traditional' strangers as the Mandingo are often identified. In relation to landlord-stranger reciprocity relations, this demonstrates that strangers are differentiated from 'outsiders' like aliens all together. Strangers are recognised and considered as part of a community by their hosts, albeit with a different status, whereas outsiders, or aliens in this case, are not recognised within the same reals. The line between the war and the post-war moment here is continued:

No Mandingo Karnplay man killed any Karnplay Dan man, or the other way around, no. We cannot carry anybody to police or court. The chief will talk between us. If you carry it to police, it is not between a real Karnplay Mandingo or real Karnplay Dan. Any penalty they give you, you will pay. The people who are doing bad things, they come from outside. They enter in the town and do bad things.

The shared experiences during the war in this part of Nimba County vary considerably from other parts of the country such as Lofa County or the city of Ganta. These various experiences allow for the Mandingo in Karnplay to inscribe themselves into the logic of landlord-stranger reciprocity. In other parts of the country, the war was fought more intensely at different moments in time and by different actors, which makes people in different regions have different experiences of violence and war, according to my observations.

As a second explanation, besides the shared experiences during the war, the memory of long-term co-existence, conviviality and exchange are of importance in characterising the relationship between Dan and Mandingo in the post-war moment beyond stereotypical dichotomies. Here it is key to remember that the migration of Mandingo among the Dan occurred much more gradual and peaceful than it did among the neighbouring Loma in Lofa County. The historical premise on which relationships are forged between both groups is therefore rather different. Two empirical examples shed light on how these relationships are constituted. First, over the years, there have been several religious conversions from Christianity to Islam of key historical figures. Second, there are continued negotiations over land rights within the context of landlord-stranger reciprocity.

Contrary to what might be expected in the post-war era in which ethnic identity is supposedly politicised, the local Imam of the Karnplay Mosque is a Dan man. Although this could be seen as a way to keep their strangers in check and to keep control of what they are doing in the secluded space of the mosque, there is a strong discourse of inclusion in this regard. This does not in any way imply uniformity in discourse. The current Imam is a member of the Karn family and followed in his father's footsteps when he converted to Islam. He is one of only a handful of people in Karnplay who have completed the pilgrimage to Mecca, serves as the principal of the local elementary school and as one of the initiators in the establishment and later the expansion of the local radio station. For the Mandingo community, his conversion is often cited as an example of their mutual integration, while for some Dan, especially outside of the Karn family, this is seen as a form of betrayal or selling out. Before him, other prominent members of the Karn family have converted to Islam. Since the Mandingo controlled most of the business and trade in the region, chiefs and elites were never shy to be seen together and be able to 
gain access to part of their wealth. Integration in this sense works both ways and the relationship between so-called landlords and strangers works through reciprocity.

Land figured prominently in the narratives detailing a collective historical imagination set up around autochthony discourses. Access and rights to land are pivotal in discussions over autochthony and are often linked with conflict (cf. Bøas \& Dunn, 2013). In neighbouring Lofa County, for instance, tensions between Mandingo and Loma people evolve around access to and control over land. Similarly, within Nimba County in the city of Ganta, Mandingo returning from exile found their properties occupied and their claims to get it back met up with a lot of local resistance (Munive, 2010). In the case of the market ground in Karnplay, however, discussions over a potential land conflict prove more complex than a mere argument over autochthony. This narrative shows that land can be discussed without necessarily referencing autochthony and that, despite differences, it does not necessarily lead to conflict.

The place where the weekly market is being held is claimed by Mandingo traders who previously had their stores there in the past. Today, remnants of houses and leftover foundations can still be identified on the ground. Since the end of the war, a new concrete, roofed-in structure has been erected. On Wednesdays, the market attracts vendors from all over: farmers from nearby villages but also professional marketers who sell dry goods, clothes, appliances, etc. At that time, the market expands beyond the concrete structure. The parcels of land on which the marketers' stalls are placed are claimed by different Mandingo families who received the land as strangers from their Dan landlords in the past. As traders, they were given parcels of land along the main road to develop their business. ${ }^{12}$ In this case, nobody disputes the ownership of the land by Mandingo openly. Every occasion they get, Mandingo stakeholders take the chance to reiterate their ownership. In official circles, both the city and the district authorities acknowledge that this is the only land dispute in the area and that it is not so much a matter of disputing ownership but rather a matter of patience as long as the authorities are looking for an appropriate place to relocate the market.

In a more secretive way, I was travelling with some prominent Dan business men who did not, in any way, mind the current situation. They collectively stated 'let them look for a different market ground for some time, so long they don't have to give back the land to the Mandingo, it is not bad'. Also among the Mandingo there is no uniform idea about this stretch of land. During a discussion at a teashop, one younger man thought that they were not ready to receive this land anyway because they lacked the funds to develop it while somebody else insisted that it is urgent to put extra pressure on the local authorities to get this case moving. Despite these differences, consensus seems to exist that this land belongs to certain families among the Mandingo. These claims are not 'betrayed' by Dan landlords, as they would put it. This stands in contrast to other parts of the country, where landlords apparently refuse to honour pre-war arrangements. The question of when and how to return it to those families is also part of the intricate relationship between both Dan landlords and their Mandingo strangers. Moreover, in general, whereas a major frustration seemed to have existed in the past about the dominance of trade relations and networks by the Mandingo who operated from Karnplay in the pre-war years, these feelings also seem to have been subdued. Many people commented, for instance, how 'Charles Taylor opened our eyes'. Apparently, both as rebel leader and as president, he encouraged local communities to take part in trade networks. 


\section{Concluding remarks}

This article dealt with the emergence of a politicised form of ethnic awareness in the aftermath of the Liberian civil war. Through a number of empirical examples, the articulation of ethnic identities in the Liberian borderland, between Dan and Mandingo, has been analysed. In these examples, a clear divergence from the historical imagination among the Dan and other autochthonous populations emerged. Whereas the Dan emphasise their firstcomer status in the region, Mandingo stress the role they played as educators, clerics, business men and empire builders. They relate to more regional patterns of belonging and affect. These claims correspond to historical patterns of migration and interaction between various communities within the Upper Guinea Coast region. These historical patterns of migration and the role they played in building the Liberian nation are invoked to legitimise contemporary claims to citizenship. Many Mandingo were forced to leave the country during the war and are considered to be 'strangers from Guinea' by many of the autochthonous groups in the Liberian border region. The fact that they have this divergent historical imagination at their disposal makes that Mandingo are able to switch repertoires, stress autochthony and adopt a discourse that is well adapted to landlord-stranger relations in personal narratives. However, in doing so, Mandingo will most often adopt the position of stranger rather than claiming firstcomer status which fosters a sense of reciprocity and potential for integration rather than exclusion. Following the idea behind landlord-stranger reciprocity relations, they are recognised and acknowledged before they are being differentiated by and from their landlords. In other words, the historical imagination that stresses mobility, movement and national achievements continues to serve as a complementary alternative to being considered a recognised stranger rather than having to compete over autochthony claims which would lead to increased tension and conflict.

\section{Notes}

1. The notion of historical imagination in the case is based on the work of Højbjerg (2010) dealing with the Mandingo in and around Lofa County. Others have also pointed out the significance of historical imagination as a way the past is remembered and envisioned and how this informs present-day social relations. See Comaroff and Comaroff (1992), d'Azevedo (1962b) and Shaw (2002).

2. For an overview of the structural elements of these communities, see d'Azevedo (1962a). For more on the historical representation of the interior in early Liberian writing, see Fairhead, Geysbeek, Holsoe, and Leach (2003).

3. This use of the distinction between landlords and strangers differs slightly from the way it is used by authors like Cohen $(1965,1966,1969)$ or George Brooks $(1993)$ who discuss the role of international traders settling along the Upper Guinea Coast and deal with exchange rather than marriage or kinship ties.

4. Benjamin Anderson was an Americo-Liberian explorer who travelled several times (1868-1869 and 1874) into the interior in search of the mythical city of Musadu which was believed to be a centre of education, trade and civilisation in comparison to the 'primitive' forest people of the interior (Fairhead et al, 2003).

5. In her contribution, Bräuchler (2017) also points to the cultural dimension of migration and the way this influences identity politics in the Indonesian context.

6. Landlord-stranger reciprocity relations only formed later on as Mandingo settled among local communities more permanently. 
7. Ford (1990, p. 264) elaborates on the role played by the Mandingo in setting up local and regional markets throughout the hinterland. Even though control over the trade routes was not always in their hands, they have been instrumental in developing a culture of exchange.

8. They claim the school and the mosque were established by 1924 .

9. These local differences go against the regional explanations of the war (Chauveau \& Richards, 2008). Højbjerg (2016) has argued for a similar differentiation by pointing out that among the Loma, Mandingo make collective claims to political leadership, whereas in cities like Ganta, rights to land and property are fought on an individual basis. A larger, collective mobilisation has, so far, not taken place in this region.

10. There is a new mosque under construction in Karnplay, but it has been in the same state since before the war. The Mandingo community has received donations from the Middle East and bought the materials to build the mosque. Because of the war, however, the construction work was put on hold and today they lack the resources to buy the necessary material to finish the building.

11. The representation of this narrative here is paraphrased because of reasons of privacy and anonymity.

12. In the aftermath of the war, in 2009 , a presidential commission has been established and made up of local representatives to deal with land conflicts. Even though the commission stopped working after 6 months into its activities since its operating budget was depleted, it dealt with over 50 cases. Today, INGOs have taken over negotiations on land disputes that are attempted to be settled outside of the court.

\section{Disclosure statement}

No potential conflict of interest was reported by the author.

\section{References}

Ammann, C., \& Kaufmann, A. (2014). Politics of ethnicity in Monrovia, Liberia and Kankan, Guinea - a comparative analysis. Mande Studies, 14, 57-98.

Bøas, M. (2009). 'New' nationalism and autochthony: Tales of origin as political cleavage. Africa Spectrum, 44(1), 19-38.

Bøas, M., \& Dunn, K. (2013). Politics of origin in Africa: Autochthony, citizenship and conflict. London: Zed Books.

Borch, S. (2017). In 'no man's land': The im/mobility of Serb NGO Workers in Kosovo. Social Identities. doi:10.1080/13504630.2017.1281470

Bräuchler, B. (2017). Changing patterns of mobility, citizenship and conflict in Indonesia. Social Identities. doi:10.1080/13504630.2017.1281468

Bräuchler, B., \& Ménard, A. (2017). Patterns of im/mobility, conflict and the re/making of identity narratives. Social Identities. doi:10.1080/13504630.2017.1281418

Brooks, G. (1993). Landlords and strangers: Ecology, society, and trade in Western Africa 1000-1630. Boulder, CO: Westview Press.

Chamberlain, M., \& Leydesdorff, S. (2004). Transnational families: Memories and narratives. Global Networks, 4(3), 227-241.

Chauveau, J. P., \& Richards, P. (2008). West African insurgencies in agrarian perspective: Côte d'Ivoire and Sierra Leone compared. Journal of Agrarian Change, 8(4), 515-552.

Cohen, A. (1965). The social organisation of credit in a West African cattle market. Africa, 35, 8-20.

Cohen, A. (1966). Politics of the kola trade. Africa, 36, 18-36.

Cohen, A. (1969). Custom and politics in urban Africa: A study of Hausa migrants in Yoruba towns. Berkeley: University of California Press.

Comaroff, J., \& Comaroff, J. (1992). Ethnography and the historical imagination. San Francisco, CA: Westview Press. 
d'Azevedo, W. (1962a). Some historical problems in the delineation of a Central West Atlantic region. Annals of the New York Academy of Sciences, 96, 512-538.

d'Azevedo, W. (1962b). The use of the past in Gola discourse. The Journal of African History, 3(1), $11-$ 34.

d'Azevedo, W. (1994). Phantoms of the hinterland: The 'Mandingo' presence in early Liberian accounts. Liberian Studies Journal, 19(2), 197-242.

Ellis, S. (1999). The mask of anarchy: The destruction of Liberia and the religious dimensions of an African civil war. London: Hurst.

Fairhead, J. (2010). Kouankan and the Guinea-Liberian border. In J. Knörr \& W. Trajano-Filho (Eds.), The powerful presence of the past. Historical dimensions of integration and conflict in the Upper Guinea Coast (pp. 75-100). Leiden: Brill.

Fairhead, J., Geysbeek, T., Holsoe, S., \& Leach, M. (Eds.). (2003). African-American exploration in WestAfrica: Four nineteenth-century diaries. Bloomington: Indiana University Press.

Ford, M. (1989). Pacification under pressure: The political economy of the intervention in Nimba 1912-1918. Liberian Studies Journal, 14(2), 44-63.

Ford, M. (1990). Ethnic relations and the transformation of leadership among the Dan of Nimba, Liberia (ca. 1900-1940) (Unpublished Ph.D. dissertation). State University of New York, Binghamton.

Ford, M. (1995). The political economy of taxation in Liberia, ca. 1830-1930. Research in Economic Anthropology, 16, 397-419.

Fortes, M. (1975). Strangers. In M. Fortes \& S. Patterson (Eds.), Studies in African social anthropology (pp. 229-253). London: Academic Press.

Gershoni, Y. (1985). Black colonialism: The Americo-Liberian scramble for the hinterland. Boulder, CO: Westview Press.

Geysbeek, T. (2002). History from the Musadu epic: The formation of Mandingo power on the Southern Frontier of the Mali Empire (Unpublished Ph.D. dissertation). Michigan State University, East Lansing, MI.

Glick Schiller, N., \& Salazar, N. (2013). Regimes of mobility across the globe. Journal of Ethnic and Migration Studies, 39(2), 183-200.

Guyer, J., \& Belinga, S. (1995). Wealth in people as wealth in knowledge: Accumulation and composition in equatorial Africa. The Journal of African History, 36(1), 91-120.

Højbjerg, C. (1999). Loma political culture: A phenomenology of structural form. Africa, 69(4), 535554.

Højbjerg, C. (2010). Victims and heroes: Manding historical imagination in a conflict-ridden border region (Liberia-Guinea). In J. Knörr \& W. Trajano-Filho (Eds.), The powerful presence of the past. Historical dimensions of integration and conflict in the Upper Guinea Coast (pp. 273-293). Leiden: Brill.

Højbjerg, C. (2016). The 'Mandingo question': Transnational identity and violent conflict in an Upper Guinea border area. In J. Knörr \& C. Kohl (Eds.), The Upper Guinea Coast in global perspective (pp. 255-279). New York, NY: Berghahn.

Holsoe, S. (1966). The Condo Federation in Western Liberia. The Liberian Historical Review, 3(1), 1-28.

Kohl, C., \& Schroven, A. (2014). Suffering for the nation: Bottom-up and top-down conceptualisation of the nation in Guinea and Guinea-Bissau (Working Paper 152). Halle: Max Planck Institute for Social Anthropology.

Konneh, A. (1992). Indigenous entrepreneurs and capitalists: The role of the Mandingo in the economic development of modern-day Liberia (Unpublished Ph.D. dissertation). Indiana: Indiana University.

Lentz, C. (2013). Land, mobility and belonging in West Africa. Bloomington: Indiana University Press.

Le Page, R. B., \& Tabouret-Keller, A. (1985). Acts of identity: Creole based approaches to language and identity. Cambridge: Cambridge University Press.

Ménard, A. (2017). Interpreting conflict and integration through the reciprocity lens: Mobility and settlement in a historical perspective on the Sierra Leonean coast. Social Identities. doi:10.1080/ 13504630.2017.1281459

McGovern, M. (2012). Life during wartime: Aspirational kinship and the management of insecurity. Journal of the Royal Anthropological Institute, 18(4), 735-752. 
Munive, J. (2010). Ex-combatants, returnees, land and conflict in Liberia (Working Paper 5). Copenhagen: DIIS.

Murphy, W., \& Bledsoe, C. (1987). Kinship and territory in the history of a Kpelle Chiefdom (Liberia). In I. Kopytoff (Ed.), The African frontier: The reproduction of traditional African societies (pp. 123-147). Bloomington: Indiana University Press.

Person, Y. (1971). Ethnic movement and acculturation in Upper Guinea since the fifteenth century. African Historical Studies, 4(3), 669-689.

Radcliff-Brown, A. R. (1940). On joking relationships. Africa, 13(3), 195-210.

Richards, P., Archibald, S., Beverlee, B., Modad, W., Mulbah, E., Varpilah, T., \& James, V. (2005). Community cohesion in Liberia: A post-war rapid social assessment (Social Development Paper No. 21). Washington, DC: The World Bank.

Shaw, R. (2002). Memories of the slave trade: Ritual and the historical imagination in Sierra Leone. Chicago, IL: University of Chicago Press.

Tonkin, E. (1990). West African ethnographic traditions. In R. Fardon (Ed.), Localizing strategies: Regional traditions of ethnographic writing (pp. 137-151). Edinburgh: Scottish Academic Press.

Trajano Filho, W. (2010). The creole idea of nation and its predicaments: The case of Guinea-Bissau. In J. Knörr \& W. Trajano Filho (Eds.), The powerful presence of the past. Historical dimensions of integration and conflict in the Upper Guinea Coast (pp. 157-184). Leiden: Brill. 